\title{
Article
}

\section{Gender diversity on Boards and Forward- looking Information Disclosure: Evidence from Jordan}

Aribi, Zakaria Ali, Alqatamin, Rateb Mohammad Hamed and Arun, Thankom Gopinath

Available at http://clok.uclan.ac.uk/21803/

Aribi, Zakaria Ali ORCID: 0000-0001-7772-2341, Alqatamin, Rateb Mohammad Hamed and Arun, Thankom Gopinath (2018) Gender diversity on Boards and Forward-looking Information Disclosure: Evidence from Jordan. Journal of Accounting in Emerging Economies, 8 (2). pp. 205-222. ISSN 2042-1168

It is advisable to refer to the publisher's version if you intend to cite from the work. http://dx.doi.org/10.1108/jaee-05-2016-0039

For more information about UCLan's research in this area go to http://www.uclan.ac.uk/researchgroups/ and search for <name of research Group>.

For information about Research generally at UCLan please go to http://www.uclan.ac.uk/research/

All outputs in CLoK are protected by Intellectual Property Rights law, including Copyright law. Copyright, IPR and Moral Rights for the works on this site are retained by the individual authors and/or other copyright owners. Terms and conditions for use of this material are defined in the policies page.

\section{CLoK}

Central Lancashire online Knowledge www.clok.uclan.ac.uk

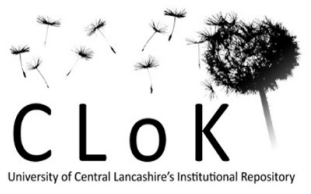




\section{Gender diversity on Boards and Forward-looking Information Disclosure: Evidence from Jordan}

\section{Introduction}

Academic and Policy interest in greater diversity in the boardrooms is rapidly increasing and has become a major debate in the corporate governance literature. For example, a number of studies have analyzed the impact of women in corporate boards on different aspects of the management such as decision-making, risk taking, general firm performance and value of the firm. Nevertheless, little direct evidence exists on the relation between gender diversity on the board of directors and voluntary disclosures (Peterson and Philpot, 2007; Adams et al., 2009; Arun et al., 2015). This paper contributes to this debate by examining the issue of gender diversity in corporate boards. A substantial amount of research, suggests that firms with a high percentage of female members on the board and at top management level perform better than those without (Carter et al., 2003; Erhardt et al., 2003; Campbell and MínguezVera, 2008; Adams et al., 2009). The evidence suggests that female representation on the board might add unique viewpoints to the boardrooms, work styles, and different experiences as compared to their male counterparts which is likely to improve the creativity and quality of the board decisions (Daily et al., 2003; Smith et al., 2006). Further to this, the literature suggests that female directors improve firm disclosure through better monitoring (Gul et al., 2011b). However, the research on the impact of female directors on voluntary forwardlooking Information Disclosure (FLID) statements is sparse. We were motivated by this gap and the evidence which reveals that financial reporting practices vary with the individual characteristics of directors (Dikolli et al., 2012; Schrand and Zechman, 2012; Davidson et al., 2013). In particular, we examine the role played by female directors on FLI statements, using the narrative disclosures from the annual financial reports of non-financial Jordanian companies listed on the Amman stock exchange (ASE).

This study is conducted in Jordan, a developing country situated in the Western region of Asia, which has an open economy. Its economic philosophy is based on the adoption of a market economy and liberalization of trade, which makes it capable of adopting its own local laws in line with those of its international counterparts (Aljifri and Khasharmeh, 2006). ASE, the biggest stock market in the region, works in close collaboration with the Jordan Securities Commission (JSC) on surveillance matters and has a strong relationship with other exchanges, associations and international organizations. The Jordanian capital market is 
mature by regional standards and integrates with Middle East market, which implies little long-run risk diversification (Saadi-Sedik and Petri, 2006). Previous studies found that managers in family companies are more likely to disclose more FLID than those managing non-family companies (Ali et al. 2007; Chau and Gray 2010). The Jordanian capital market consists of a relatively large fraction of family-controlled companies, there were 128 (64 percent) family companies and 73 (36 percent) non-family companies listed on the ASE over the period 2008-2013 (ASE, 2015). Thus, this setting in Jordan provides an opportunity for managers to disclose more information. We assumed that the issue of gender diversity on boards in family/non family companies is worth investigating. Since 2007, the ASE has insisted that, all listed companies required to increase the credibility and transparency of financial reporting by adopting the International Financial Reporting Standards (IFRS), and the listed companies enhanced their voluntary disclosure since then. Furthermore, the Government of Jordan has introduced numerous reforms through accounting regulations, securities exchange laws and corporate disclosure practices. These reforms contribute to more transparent markets and the listed companies have enhanced their voluntary disclosure (AlFayoumi et al., 2010; Al-Akra and Ali, 2012; JSC, 2015).

The Jordanian capital market began to be transformed from a public to a private market. Moreover, the practice of corporate governance in Jordan began in 2008 and the corporate governance code number 15 requires that the fraction of female on the board of directors should be increased among all listed companies (Abed et al. 2012). Sartawi et al. (2014) found that the percentage of female directors of Jordanian companies is 5\%. Jordan, therefore, provides a unique national context in which to investigate the link between the narrative disclosure of FLI and gender diversity on boards among non-financial companies listed on the ASE during the period 2008 - 2013. The current study argues that non-financial Jordanian companies with a high percentage of female members on the board and at top management level are more likely to disclose more FLI. There are very limited number of studies that have examined the disclosure of FLI in developing countries and even fewer such studies may be found in Middle Eastern countries.

This study provides one the very first evidence on the impact of gender diversity on the board on the level of FLID, in a developing country context. Our results reveal that FLID by companies are positively associated with gender diversity on board. Since gender diversity of boards and voluntary reporting are two most debated issues in the corporate World, this study provides evidence that gender diversity on board is one of the attributes influencing the voluntary FLID. In addition, our results reveal that companies with CEO females are more 
likely to disclose more FLID. Furthermore, we use a unique setting, family versus non-family firms, to further examine the effect of ownership structure, specifically family ownership, on voluntary disclosure. Prior studies reveal that voluntary disclosure leads to lower bid-ask spreads, lower information risk, and lower cost of raising capital (Welker, 1995; Botosan, 1997; Healy and Wahlen, 1999). The results suggest that family companies, who stand to gain greater benefits, would prefer more public disclosure, and shows a significant positive relationship. The findings are useful for the policy community who are concerned with the impact of governance structure on corporate disclosure.

The remainder of the paper proceeds as follows. Section 2 presents a literature review and section 3 presents our research design. The main results are discussed in section 4 , and we provide a summary of our results and conclusion in section 5 .

\section{Literature review and hypotheses development}

\subsection{Gender diversity on the board and voluntary disclosure}

There is a widely held assumption prevailed in the academic and policy circles that the gender structuring of the corporate boards will bring alternate views and transparency in the corporate decision making process. The prior literature documented the difference between male and female in terms of personality, communication style, decision-making, risk taking, leadership, expertise and general performance in business (e.g. Johnson and Powell, 1994; Bilimoria, 2000; Peterson and Philpot, 2007; Dowling and Aribi, 2013) which implies that women present an alternative perspective which requires attention in all areas of corporate governance. The extent to which the difference between females and males might apply to the decisions on corporate reporting which has largely been resolved as an empirical question. Coffey and Wang (1998) found that women directors are less self-interest oriented which improve decision making process and enhance board effectiveness. Post et al. (2011) argue that gender diversity on the board of directors improve the chances that different types of knowledge, ideas, and perspectives will be considered in the decision-making process. Women brings different viewpoints to the boardroom which facilitate informed decisions (Daily et al., 2000; Rose, 2007) with an increasing transparency in decision making. Politically, Brammer and Pavelin (2006) find that having more women on boards enhances reputation, and Campbell and Mínguez-Vera (2008) found a positive market reaction in the short term to the announcement of female board appointments.

The disclosure of FLI may be viewed as a key aspect of financial reporting quality since this information is more likely to be perceived as being of higher quality (Karamanou and 
Vafeas, 2005; O'Sullivan et al., 2008). Since FLID capture current plans and future forecasts (Hussainey et al., 2003), the lack of sufficient FLID may end up with volatile stock prices and uncertainty in investments. The "traditional" reporting, largely based on financial statements has been questioned in terms of its ability to meet the increasing information needs (Michelon et al., 2015). It is quite challenging for many users understand the elements of financial statements without narrative explanations due to the increasing complexity of regulations, business contexts, firm's strategies and operations makes. In fact, narrative disclosures contribute not only through the clarification of quantitative and financial measures but also through the identification of value-generation drivers not represented well in the financial statements (e.g. Schleicher et al., 2007; Souabni, 2011; Michelon et al., 2015).

Gender diversity on board improves disclosure quality through better control of the managers that increase the transparency and promotes active board communication to investors. For example, Srinidhi et al. (2011) find that gender diversity on boards is positively related to audit effort and earnings quality. They find that female directors on the board and audit committees enhances the company's reporting integrity and investors' confidence in financial reporting. However, in contrast to these findings, Sun et al. (2011) found no evidence for the impact of female representation on audit committees and earnings management. Liao et al. (2014) provide evidence that gender diversity on the board is positively associated with financial and nonfinancial information disclosure. Suggesting that, companies with a higher proportion of gender diversity of the board are more likely to disclose more FLID, the findings of Gibbins et al. (1990); Nalikka (2009) and Sartawi et al. (2014) provided further evidence that gender diversity is one of the attributes influencing positively the voluntary information disclosures in annual reports. In the same vein, Barako and Brown (2008) reported that a higher level of female representation and independent directors significantly enhance corporate disclosure. A recent study by Thankom et al. (2015) examines the relationship between female director and earnings management in the UK. They found firms with a higher number of female and independent female directors are adopting restrained earnings management and tend to adopt more conservative accounting policies compared with those companies with a lower number of female and directors.

Building on the above discussion, we propose our first hypothesis as:

H1: There is a positive relationship between the proportion of female on the board of directors and the level of FLID. 


\subsection{CEO's gender and voluntary disclosure}

Previous studies suggest that the gender of company executives has an influence on corporate decisions and that female executives tend to take a different perspective and demand different information than their male counterparts (Krishnan and Parsons, 2008; Sun et al., 2011; Srinidhi et al., 2011). However, the extent to which gender influences corporate reporting decision-making remains unclear. For example, Ge et al. (2011) found no significant relationship between CFOs' gender and accounting choices, while Krishnan and Parsons (2008) found that gender diversity in senior management affects the quality of reported earnings. Similarly, Gul et al. (2011a) examined whether the gender of directors affects fully independent audit committees' ability to constrain earnings management and thus their effectiveness in overseeing the financial reporting, finding that the proportion of females on the audit committee is not associated with earnings management. Jia et al. (2014) investigated the relationship between the facial structure of CEOs and their companies' financial misreporting, and the results showed that companies with CEOs who have more masculine faces have a higher incidence of financial misreporting. Recent studies by Ho et al. (2015) and Thankom et al. (2015) found that female directors tend to adopt more restrained earnings management, reflecting an inclination towards more conservative accounting policies, and a more conservative mind-set among female CEOs characterised by a tendency to be less aggressive.

H2. The level of FLID is positively associated with female CEOs among non-financial Jordanian companies.

\section{Research design}

\subsection{Measuring the level of FLI disclosures:}

Content analysis was utilized to gather and explore the items of FLID in our sample, as extensively reported in the literature as a powerful tool to explore corporate disclosures ( e.g. Cunningham and Gadenne 2003; Mathuva 2012; Menicucci 2013). In addition, the disclosure index approach has bees used to measure the level of FLID (Maali et al. 2006). The decision to focus on the level of disclosures is often employed as a proxy for disclosure quality (Beattie et al., 2004; Beretta and Bozzolan, 2008). The level of FLID may be viewed as a key aspect of financial reporting quality since this information is more likely to be perceived as being of higher quality (Karamanou and Vafeas, 2005; O'Sullivan et al., 2008). This is useful in identifying specified characteristics of messages in a systematic manner (Carney (1972, p. 
p.21) which allows codifying textual content into different categories depending on selected criteria (Haniffa and Hudaib, 2007). We treat the FLID items in the paper, using a list of 35 forward-looking keywords such as anticipate, accelerate, coming year (Hussainey et al. 2003). The disclosure index includes five categories, and twenty-seven items (See Appendix 1).

We have employed three steps to make sure the reliability and validity of the content analysis process: (1) Developed a set of specified and explicit coding instruments to minimize discrepancies, and ensure objectivity (2) Five annual reports have been tested by several coders to ensure that, all coders adopt the same coding procedures, to resolve the differences between the codes (3) the coding rules for classification of categories and checklist items are re-confirmed by five different professional accountants and the results were compared to identify possible disagreements. Our approach to score FLID items is dichotomous in that a FLID item scores value of one if disclosed otherwise zero, and the approach to scoring is detective and equally weighed. To measure the extent of FLID, we expressed the scores in the form of an index, which we called FLID index (e.g. Cerf, 1961; Rizk et al., 2008). The disclosure index was constructed as a ratio obtained by dividing the number of FLID items disclosed by the total number of FLID items for each company (e.g. Cerf, 1961; Rizk et al., 2008; Muttakin et al., 2015).

This study used the following disclosure index to measure the level of FLID:

\section{$\mathrm{FWD}=\sum d i$}

Where FWD refers to the forward-looking category disclosed and di = one if the category contains forward-looking items and zero if not.

The FLI disclosures index for each company is set as FWD/TDS

Where

TDS is the maximum disclosure provided by the companies in their published annual financial reports.

\subsection{Empirical models}

We measured gender diversity on the board of directors in two ways. First, as a percentage of female directors computed by divided female numbers on the board on the total number of the board (POFOB). Second, the number of female directors on the board of directors 
(NOFOB) (Campbell and Mínguez-Vera, 2008; Gul et al., 2011b). CEO's gender is a dummy variable where the value 1 given if the CEO female and zero otherwise. We control for company-specific characteristics that may affect the level of FLID. These control variables are Company size, profitability, dividends, leverage and industry type. Prior studies suggested that, these company-specific characteristics may affect the level of FLID (Jensen and Meckling, 1976; Wallace et al., 1994; Beattie et al., 2004; Marston and Polei, 2004; Alsaeed, 2006; Celik et al., 2006; Aljifri and Hussainey, 2007; Wang et al., 2008; Uyar and Kilic, 2012; Alkhatib, 2014). Since agency cost depends on the firm's size, the agency theory assumes that larger companies perform a greater number of complex business transactions and are more likely to publish voluntary disclosures to decrease the costs (Pérez, 2004). Several studies have found a positive relationship between company size and the level of voluntary disclosures (Barako et al., 2006; Salama et al., 2012; Al-Najjar and Abed, 2014; Jizi et al., 2014; Qu et al., 2015). In respect to firm profitability, Alkhatib and Marji (2012) and Uyar and Kilic (2012) found that companies with high profits are motivated to disclose more information than those with small profits. With respect to dividends and FLID, this study considers dividend policy as one of its key drivers. Recently, the relationship between the level of FLID and the firm's dividend policy has gained considerable attention. For example, Hussainey and Walker (2009) argued that FLID and dividend payments are alternative methods to convey important information to investors. In respect to the relationship between the financial leverage ratio and the level of FLID, agency theory claims that highly leveraged firms have a greater contractual obligation to fulfil the information requests of long-term and short-term lenders, and therefore may offer more details to meet those needs than would a less leveraged company (Watson et al., 2002; García-Meca and Sánchez-Ballesta, 2009). The literature has reported that leverage ratio has an effect on the level of FLI disclosures (Deshmukh, 2005; Li and Zhao, 2008; O'Sullivan et al., 2008; Hussainey and Walker, 2009; Basiddiq and Hussainey, 2012; Al-Najjar and Abed, 2014). Sector type is another determinant of company information disclosure (Celik et al., 2006, Alkhatib and Marji, 2012), where mixed results were found.

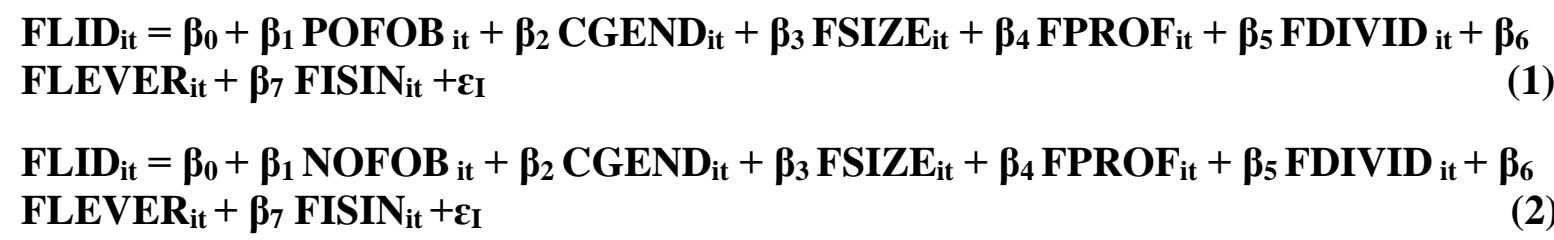

Where: 
FLIDit= Forward-looking disclosure index of the I company in the $t$ year, expressed as percentage total FLI disclosed out of all items.

$\mathrm{POFOB}=$ the proportion of females on the board of director measured by dividing the number of females on board by total numbers of the board.

$\mathrm{NOFOB}=$ the numbers of female on the board of director.

CGEND= CEO's gender, take the value one if CEO, male and 0 if CEO female.

FSIZE $=$ Firm size, natural log of firm's total assets.

$\mathrm{FPROF}=$ profitability, measured by ROI (net income before tax divided be total assets). FDIVID= dividend ratio measured as cash dividends divided by net income for the same period.

FLEVER = leverage ratio, measured by total long-term debt divided by total assets.

FISIN = industry type, measured by using the isin code as stated by the Jordanian Securities Depository Centre.

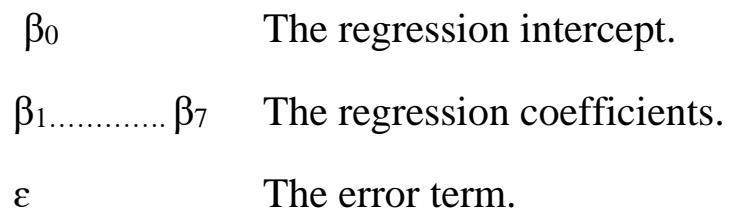

\subsection{Sample selection and data collection:}

The sample covers the period 2008-2013. In 2008, the Amman Stock Exchange (ASE) has introduced new reforms for accounting regulations; securities exchange laws, and corporate disclosure practices, which contribute to more voluntary disclosure and transparent markets (Al-Akra and Ali 2012). Our initial sample for the study is the 270 companies listed on the ASE. However, we have removed all financial companies (42 companies) from the initial sample due to their unique characteristics and specific regulations and disclosing requirements which may have an impact on the results. In addition, companies with missing data been removed from the initial sample. The final sample consists of 1206 firm-years observations during the study period. Table 2 displays the final sample sorted by industry.

Data were collected from the annual reports published in the years 2008-2013. The data of directors' gender is collected through different sources - annual reports, company web page, press releases, and direct communication with companies. Most of the annual reports are 
available on the websites of the companies on a yearly basis. Botosan (1997) demonstrated that the annual reports provide a good proxy and comprehensive resource for the information disclosed by a firm. Most companies release their annual reports within the first quarter of the year, after the fiscal year. The annual reports are considered as a primary source of voluntary disclosure to the user group (e.g. Neu et al., 1998). Annual reports are considered more readily comparable among companies than other less formal communication channels, such as press releases, or direct contact analysts (Chang and Most, 1985). Furthermore, to cover some missing financial information in the annual reports, web sites of the Securities Depository Centre, Amman Stock Exchange, and OSIRIS databases were used as additional sources. Table 1 reports the sample based on industry type.

\section{Insert Table 1 about original distribution of the sample about industry}

\section{Results and discussion}

\subsection{Descriptive statistics}

The descriptive findings are summarized in Table 2. For our sample, the minimum value of the FLI disclosures rate is $0 \%$, and the maximum is $78 \%$. The findings indicate a considerable dispersion in the rates of FLI disclosures which reveals the variation occurs in Jordanian companies in term of their decision to change FLID from year to year. The mean value $31.14 \%$ shows that a low level of FLID across the companies, with a standard deviation equal $18.44 \%$. This study employed the median value $33 \%$ as a benchmark to classify the high and low level of FLID.

In terms of the proportion of females on the board, the mean value is $4.39 \%$, and the lowest and highest percentage female on the board is 0 and $60 \%$ respectively. This finding is expected since the majority of Jordanian companies are owned by families. As in this study, Sartawi et al. (2014) found that the percentage of female directors of Jordanian companies is $5 \%$. The study has used a number of females on the board as a second proxy to measure gender diversity. Table 2 shows that the mean value of the number of female on the board is $24.70 \%$ with standard deviation value $43.15 \%$ and minimum, and maximum values are 0 and 6 respectively. This result is consistent with the prior study of Gavious et al. (2012) who find that the average number of women directors among Israel firms is one, and the maximum is 5. Regarding CEO gender, Table 2 shows that $95.19 \%$ of the sample companies managed by male CEO. In our sample, $95 \%$ of companies managed by males and $5 \%$ of female CEOs. 
This is an interesting finding, similar to the 5\% obtained in Ireland, New Zealand and the United Arab Emirates (Grant Thornton International Business Report 2012), and quite close to the percentages for the USA and UK ( $6 \%$ females in both countries), but higher than the $3 \%$ in Japan, Brazil and Botswana. Company's size determined as the natural logarithm of total assets has a mean of (1801419) the minimum value of company size is (412636) and the maximum value is (28802374). Values of Company's size indicate that companies are widely dispersed. The results of the profitability reveal that profitability varies between minimum values $-85.90 \%$ (Loss) and 95\% (Maximum profit). In addition, Table 2 shows that the mean value of dividend ratio is $18.82 \%$, and, minimum and maximum values are 0 and $97.51 \%$, respectively. It is also seen that the average value of the leverage ratio is $29.50 \%$, and the minimum and maximum values are $0.002 \%$ and $97.80 \%$. The mean value of industry type indicates that $36.31 \%$ of sample companies operating in the industrial sectors.

\section{Insert Table 2 about descriptive statistics}

Before conducting the regression analysis, we tested whether there was an econometric problem in the model used to examine the impact of gender diversity on boards on the level of FLID. As a first step, the multicollinearity problem was tested by using correlation matrices. Table 3 shows that the highest correlation is between the dividend ratio and the firm's profitability with a coefficient of $37 \%$. According to Gujarati (2008), a coefficient of \pm 80 per cent is considered as the point at which serious multicollinearity problems might exist and harm the results of the regression analysis. Therefore, the problem of multicollinearity does not exist among the data set used in this model.

\section{Insert Table 3 about correlation matrix}

\subsection{Multivariate analysis}

The panel data allow us to remove any unobservable heterogeneity problem that might be existent among the companies in our sample. Panel data models can be specified as fixed effect or random effect to capture the impact of companies and specific time heterogeneities. We performed Housman test, which examines the equality of the fixed and random effect estimations. The test statistic outcome is not statistically significant (P-Value $=0.3107)$, and consequently we estimate random effect models. Pesaran CD test has been employed to 
check whether the model has serial correlation or not, and the test result is not statistically significant $(\mathrm{P}-$ Value $=0.4237)$. Modifier's Wald test outcome $(\mathrm{P}-$ Value $=0.5928)$ indicated that no heteroscedasticity in our model.

The results of regression analysis are presented in Table 4. The estimates are presented on two panels: Panel A) reports the results for the regressions where the gender diversity on the board of directors is measured by using percentage. While, the gender diversity on the board of directors in panel B) is measured based on the numbers of female on the board of directors. As can be seen from Table 4 , the $\mathrm{R}^{2}$ values are varying between $55.6 \%$ and $54.7 \%$, respectively, which mean the combination of the independent variables demonstrates $55.6 \%$, $54.7 \%$ of the variation of the dependent variable respectively. The P-Values are highly significant at the level 0.000, implying that the models are highly significant and thus have a good explanatory power of disclosure.

Results of both panels show a significant positive relationship between the gender diversity on the board of directors and the level of FLID, and support H1. This finding is consistent with studies that reported a significant positive association between percentage of female on the board of directors and voluntary disclosure (e.g. Nalikka, 2009; Sartawi et al., 2014). The results of this study indicate that if more women directors are on the board, the more information is voluntarily disclosed by the company. The significant positive coefficient at level 0.016 of female CEOs suggests that companies with high CEO's female are more likely to disclose more FLID than those companies with low CEO's female. This finding supports $\mathrm{H} 2$, which proposes a positive relationship between the level of FLID and female CEOs, In addition, these findings confirm that Jordanian companies with high female CEOs are more likely to improve the quality of their financial reports by extending the level of FLI disclosures. This finding is not surprising since the Jordanian economy is private sector oriented; the owner-largest shareholder in Jordan, typically a founder or his immediate family usually involve in company management directly or indirectly and effects most of the manager's decisions. This result is consistent with prior studies (Siciliano, 1996; Erhardt et al., 2003). In regard to the control variables, the regression results indicate that profitability, dividend ratio, and the leverage ratio variables are found to have a positive influence on the level of FLID in both panels. For example, the findings of the study show that companies with high profits are motivated to disclose more information than those with small profits. Furthermore, these results confirm that Jordanian companies with higher dividend ratio tend to use FLLD and dividend payments, as alternative methods to convey important information to investors. In respect to the relationship between the financial leverage ratio and the level of 
FLID, the findings are consistent with agency theory's perspective; that highly leveraged firms have a greater contractual obligation to fulfil the information requests of long-term and short-term lenders, and may offer more details to meet those needs than a less leveraged company (Watson et al., 2002; García-Meca and Sánchez-Ballesta, 2009). The results are consistent with prior studies which suggest that, companies with higher profitability, dividend, and leverage ratio are more likely to disclose additional voluntary information to increase their investor's confidence (Alkhatib and Marji, 2012; Uyar and Kilic, 2012). The results of the study are also consistent with Aljifri and Hussainey (2007) and Aljifri (2008) who reported that firms of varying sizes have no difference in their FLID.

\section{Insert Table 4 about the association between percentages of female on the board of directors, female CEOs and FLID.}

\subsection{Further analysis}

We test the level of agency problem among family and non-family companies in the context of their voluntary disclosure practices. The existing evidence indicate that family companies face fewer agency problems because of their ability to monitor the managers (Demsetz and Lehn, 1985), which may have an impact on disclosure practices. We divided the sample into two groups, family companies and non-family firms, using Jordanian Companies Control Department Classification (2014). There are 128 (64\%) family companies and 73 (36\%) nonfamily companies were listed on the ASE over the period 2008-2013.

There are two contradictory theoretical perspectives regarding the relationship between family companies and voluntary disclosure - convergence of interest and the management entrenchment perspective (Morck et al., 1988). When the proportion of owner's shareholders is high, convergence of interest between the outside investors and owners arises since owners are less likely to act opportunistically because they face the consequences of their noncompany value- maximizing activities (Jensen and Meckling, 1976). Thus, it supports the argument that the level of conflict between inside owners and outside investor decreases as insider owner's holdings increases. Thus, the need for voluntary disclosure is reduced. The underlying rationale is that, family owners are more actively engaged in company management by being the board members and the substantial shareholders of the company. Thus, they will have better access to the company's financial and non-financial information and prefer less disclosure. However, when insiders (managers) have a large shareholding in 
their companies, they may become entrenched and follow policies that are in their own best interests. Thus, management entrenchment could happen when managers holdings are high (Morck et al., 1988). Therefore, inside owners' decisions will likely be prepared to benefit the personal interests of the owner, causing an information-asymmetry. Furthermore, confiscation of minority owners by the controlling owner could occur (Fan and Wong, 2002). Hence, outside investors will increase their monitoring of inside owner's behaviour to mitigate the agency conflict (Jensen and Meckling, 1976). While, monitoring by outside owners increase costs, which can be reduced if inside owners disclose information voluntarily. Thus, when the owner-manager holding is significant, it is expected that information disclosure is likely to be greater so that outside shareholders can successfully monitor that their economic interests are optimized. However, based on the literature, it is unclear that whether family companies prefer more or less voluntary disclosure.

We employed random effect method to examine the relationship between gender diversity on the board of director and the level of FLID. The estimation results of the random- effects panel regression analysis are presented in Table 5 (panel A and B). As can be noted from Table 5 panel A and B, regression analysis reveals a significant positive relationship between the proportion of female on the board of directors and the level of FLID among the family group. This finding is consistent with Ali et al. (2007) and Tong (2007) who found that family companies disclose better information about company's circumstance compared to non-family companies among S\&P 500 firms. Furthermore, Chau and Gray (2010) examined the relationship between the extent of voluntary disclosure and percentage of family ownership, among 273 listed companies in Hong Kong, and indicated a high proportion of family ownership is associated with higher voluntary disclosure. In addition, our results consistent with Wan-Hussin (2009) who found that family firms are more likely to disclose more information than non-family firms.

However, Table 5 (panel A and B) shows that insignificant relationship between gender diversity on the board and the level of FLI disclosures among non-family companies. These findings are consistent with Nalikka (2009) who find no significant association between the proportion of CEO female and voluntary disclosure among 108 firms listed on the Helsinki stock exchange. On the contrary, the leverage ratio has a positive correlation with gender diversity on both panels. This finding is consistent with the notion that managers of nonfamily companies may withhold bad news to maximize their compensation or to facilitate entrenchment (Ali et al. 2007). 


\section{Insert Table 5 about the association between percentages of female on the board of directors, female CEOs and the level of FLID among family and non-family company.}

\section{Conclusions}

Globally, the companies are increasingly being encouraged to provide more FLID in their reporting practices which provide a firm ground for effective decision-making. The paper provides empirical evidence on the effect of board gender diversity on the level of FLID in Jordan. The Amman stock exchange is the biggest stock market in the region and follows IFRS guidelines in corporate reporting. The study findings show that the companies with higher proportion female directors are more likely to disclose FLI disclosures compared with others. The results further indicate that companies with female CEOs tend to make more FLID compared to those companies with male CEOs. In summary, the findings signpost that gender diversity on boards positively affects the level of FLID.

Since a large proportion of Jordanian companies are family-controlled companies, we further investigate whether the relationship between gender diversity on boards and the level of FLID differ among family firms compared to non-family companies. The results show that the proportion female directors have a positive and significant relationship with the level of FLID among family companies. The findings reveal a significant positive association between female CEOs and the level of FLID in non-family companies. The findings of the study should be of interest to policymakers, regulators and academics regarding the impact of gender diversity on boards and CEO's characteristics on the level of FLID in developing countries. The findings provide empirical evidence that enables managers to assess their financial transparency and accountability, in turn helping firms to improve investors' perceptions of the quality of financial reporting. From a practice point of view, the managers need to give priority to publishing voluntary disclosures in the intended spirit. Although, this study provides stimulating insights into the effects of gender diversity on boards on voluntary disclosures, much more evidence is needed from the boardroom discussions to bring to light the shades of group dynamics in the decisions on corporate disclosures. 
Table 1. Original distribution of the sample about industry

\begin{tabular}{lcc}
\hline Description & Number & Percentage \\
\hline Educational services & 26 & $12.93 \%$ \\
Hotels and Tourism & 38 & $18.90 \%$ \\
Transportation & 23 & $11.44 \%$ \\
Commercial Services & 41 & $20.39 \%$ \\
Pharmaceutical and Medical industries & 12 & $5.97 \%$ \\
Chemical industries & 15 & $7.46 \%$ \\
Food and Beverages & 17 & $8.45 \%$ \\
Mining and Extraction industries & 14 & $6.96 \%$ \\
Engineering and Construction & 6 & $2.98 \%$ \\
Textiles, leather, and clothing & 9 & $4.47 \%$ \\
Total & 201 & $100 \%$ \\
\hline
\end{tabular}

Table 2. Descriptive statistics

\begin{tabular}{lcccccc}
\hline Variable & $\mathrm{N}$ & Minimum & Maximum & Mean & Median & Std. Deviation \\
\hline FLI & 1206 & 0 & .78 & .3114 & .33 & .1844 \\
POFOB & 1206 & 0 & .6 & .0439 & 0 & .0892 \\
NOFOB & 1206 & 0 & 6 & .2470 & 0 & .4315 \\
CEOGEN & 1206 & 0 & 1 & .9519 & 1 & .2140 \\
FSIZE & 1206 & 412636 & 28802374 & 1801 & 1.87 & 1.57 \\
FPROF & 1206 & -.85904 & .95 & .0012 & .01109 & .1217 \\
FDIVID & 1206 & 0 & .9751 & .1882 & 0 & .3077 \\
FLEVER & 1206 & .0002 & .9780 & .2950 & .2400 & .2320 \\
FISIN & 1206 & 1 & 201 & .3631 & 101 & .4811 \\
\hline
\end{tabular}

$F L I D_{i t}=$ Forward-looking disclosure index of the I company in the $t$ year, expressed as percentage total FLI disclosed out of all items. POFOB= the proportion of females on the board of directors measured by dividing the number of females on the board by total numbers of the board. NOFOB= the numbers of female on the board of directors. CEOGEN=CEO's gender, take the value one if $C E O$, male and 0 if CEO female. FSIZE = Firm size, natural log of firm's total assets. FPROF= profitability, measured by ROI (net income before tax divided be total assets). FDIVID= dividend ratio measured as cash dividends divided by net income for the same period. FLEVER=leverage ratio, measured by total long-term debt divided by total assets. FISIN= industry type, measured by using the isin code as stated by the Jordanian Securities Depository Centre. 
Table 3. Correlation Matrix

\begin{tabular}{lcccccccc}
\hline Variables & POFOB & NOFOB & CEGEN & FSIZE & FPROF & FDIVID & FLEVER & FISIN \\
\hline POFOB & 1.0000 & & & & & & & \\
NOFOB & $0.0744^{* *}$ & 1.0000 & & & & & & \\
CEGEN & 0.0008 & 0.0209 & 1.0000 & & & & & \\
FSIZE & 0.0279 & -0.0226 & 0.0215 & 1.0000 & & & & \\
FPROF & -0.0446 & -0.0551 & 0.0024 & 0.0135 & 1.0000 & & & \\
FDIVID & -0.1204 & -0.0207 & 0.0152 & $0.0688^{*}$ & $0.3714^{* *}$ & 1.0000 & & \\
FLEVER & $-0.0213^{*}$ & 0.0399 & 0.0146 & $0.0326^{*}$ & $-0.1563^{* *}$ & 0.0347 & 1.0000 & \\
FISIN & -0.0771 & -0.0702 & -0.0102 & 0.0107 & -0.0109 & 0.0021 & 0.0045 & 1.0000 \\
\hline
\end{tabular}

***. Correlation is significant at the 0.01. **. Correlation is significant at the 0.05

*. Correlation is significant at the 0.10

Table 4 Panel A: association between percentages of female on the board of directors, female CEOs and FLI disclosures.

\begin{tabular}{|c|c|c|c|c|}
\hline & Pred.sign. & Coefficient. & t-statistic & Prob. \\
\hline Cons & & .19239 & 6.30 & $0.000^{* * *}$ \\
\hline POFOB & + & .16660 & 2.27 & $0.023^{* *}$ \\
\hline CEOGEN & + & .06376 & 2.40 & $0.016^{* *}$ \\
\hline FSIZE & + & 1.5511 & 0.39 & 0.696 \\
\hline FPROF & + & 10332 & 2.28 & $0.023^{* *}$ \\
\hline FDIVID & + & .04690 & 2.62 & $0.009^{* * *}$ \\
\hline FLEVER & + & 19754 & 8.34 & $0.000^{* * *}$ \\
\hline FISIN & + & .00007 & 0.60 & 0.551 \\
\hline Adjusted $R^{2}$ & & $55.6 \%$ & & \\
\hline P. value & & 0.000 & & \\
\hline Observations & & 1206 & & \\
\hline \multicolumn{5}{|c|}{$\begin{array}{l}\text { Panel B: association between the number of females on the board of directors, female CEOs and FLI } \\
\text { disclosures. }\end{array}$} \\
\hline & Pred.sign. & Coefficient. & t-statistic & Prob. \\
\hline Cons & & .19705 & 6.50 & $0.000^{* * *}$ \\
\hline NOFOB & + & .02507 & 1.97 & $0.049^{* *}$ \\
\hline CEOGEN & + & .06198 & 2.34 & $0.020^{* *}$ \\
\hline FSIZE & + & 1.1511 & 0.29 & 0.773 \\
\hline FPROF & + & .09880 & 2.18 & $0.029^{* *}$ \\
\hline FDIVID & + & .04682 & 2.62 & $0.009^{* * *}$ \\
\hline FLEVER & + & .19781 & 8.35 & $0.000^{* * *}$ \\
\hline FISIN & + & .00005 & 0.47 & 0.642 \\
\hline Adjusted $R^{2}$ & & $54.7 \%$ & & \\
\hline$P$. value & & 0.000 & & \\
\hline Observations & & 1206 & & \\
\hline
\end{tabular}


Table 5. Panel A: association between percentages of female on the board of directors, female CEOs and FLI disclosures among and non-family family company.

\begin{tabular}{lccccccc}
\hline & \multicolumn{5}{c}{ Family company } & \multicolumn{4}{c}{ Non-family company } \\
& Pred.sign & Coeff. & $\mathrm{t}$-statis. & $\mathrm{P}[\mathrm{t}]$ & Coeff. & $\mathrm{t}$-statistic & Prob. \\
\hline Cons & & .2109 & 5.34 & $0.000^{* * *}$ & .1737 & 3.58 & $0.000^{* * * *}$ \\
POFOB & + & .2654 & 2.91 & $0.004^{* * *}$ & -.0568 & -0.46 & 0.646 \\
CEOGEN & + & .0440 & 1.31 & 0.191 & .1032 & 2.39 & $0.017^{* *}$ \\
FSIZE & - & -2.541 & -0.28 & 0.783 & 2.781 & 0.64 & 0.523 \\
FPROF & - & .0944 & 1.66 & $0.097^{*}$ & .1132 & 1.51 & 0.131 \\
FDIVID & + & .0536 & 2.28 & $0.023^{* * *}$ & .0418 & 1.52 & 0.130 \\
FLEVER & + & .1932 & 6.68 & $0.000^{* * *}$ & .2116 & 5.05 & $0.000^{* * * *}$ \\
FISIN & + & .0001 & 0.55 & 0.580 & -.0034 & -0.64 & 0.524 \\
Adjusted $R^{2}$ & & $66.4 \%$ & & & $76.4 \%$ & & \\
$P$. value & & 0.001 & & & $0.000^{* * * *}$ & & \\
$\mathrm{~N}$ & & 768 & & & 438 & & \\
\hline
\end{tabular}

Panel B: association between the number of females on the board of directors, female CEOs and FLI disclosures among family and non-family companies.

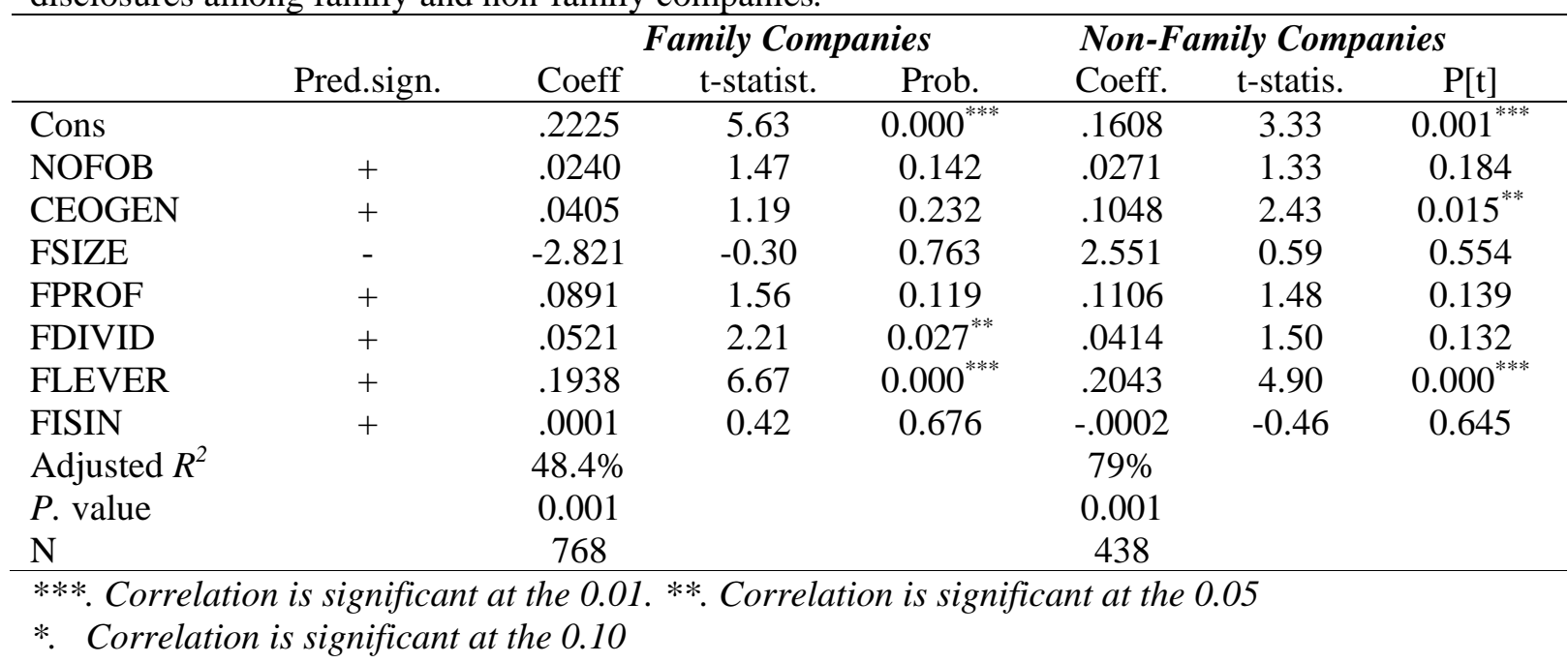




\section{Appendix 1}

FLI disclosures categories

\section{Financial FLI items}

Income.

Profit.

Loss.

Cash flow.

Capital.

Return on equity.

Sales.

Capital expenditures.

Production.

Cost.

Expenses.

Non-financial FLI items

Strategies items:

Goals for performance.

Mission.

Objectives.

\section{Company structure}

Financial structure.

Change in ownership.

Industry type.

Human and intellectual capital.

Mergers and acquisitions.

Technological structure.

\section{Environment}

Legal and regulatory.

Political.

Economic conditions.

Social responsibility.

Competitive position.

Financial and non-financial resources.

Risks.

Relationship 


\section{References}

Adams, S. M., Gupta, A. and Leeth, J. D. (2009), "Are female executives over-represented in precarious leadership positions?", British Journal of Management, Vol. 20 No.1, pp. $1-12$.

Al-Akra, M. and Ali, M. J. (2012), "The value relevance of corporate voluntary disclosure in the Middle-East: The case of Jordan", Journal of Accounting and Public Policy, Vol. 31 No. 5, pp. 533-549.

Al-Fayoumi, N., Abuzayed, B. and Alexander, D. (2010), "Ownership structure and earnings management in emerging markets: The case of Jordan", International Research Journal of Finance and Economics, Vol. 38, pp. 28-47.

Al-Najjar, B. and Abed, S. (2014), "The association between disclosure of forward-looking information and corporate governance mechanisms: Evidence from the UK before the financial crisis period", Managerial Auditing Journal, Vol. 29 No. 7, pp. 578-595.

Ali, A., Chen, T.-Y. and Radhakrishnan, S. (2007), "Corporate disclosures by family firms", Journal of Accounting and Economics, Vol. 44 No. 1, pp. 238-286.

Aljifri, K. (2008), "Annual report disclosure in a developing country: The case of the UAE", Advances in Accounting, Vol. 24 No. 1, pp. 93-100.

Aljifri, K. and Hussainey, K. (2007), "The determinants of forward-looking information in annual reports of UAE companies", Managerial Auditing Journal, Vol. 22 No. 9, pp. 881-894.

Aljifri, K. and Khasharmeh, H. (2006), "An investigation into the suitability of the international accounting standards to the United Arab Emirates environment", International Business Review, Vol. 15 No. 5, pp. 505-526.

Alkhatib, K. (2014), "The Determinants of Forward-looking Information Disclosure", Procedia-Social and Behavioral Sciences, Vol. 109, pp. 858-864.

Alkhatib, K. and Marji, Q. (2012), "Audit reports timeliness: Empirical evidence from Jordan", Procedia-Social and Behavioral Sciences, Vol. 62, pp. 1342-1349.

Alsaeed, K. (2006), "The association between firm-specific characteristics and disclosure: The case of Saudi Arabia", Managerial Auditing Journal, Vol. 21 No. 5, pp. 476-496.

Arun, T. G., Almahrog, Y. E. and Aribi, Z. A. (2015), "Female directors and earnings management: Evidence from UK companies", International Review of Financial Analysis, Vol. 39, pp. 137-146.

ASE, A. S. E. M. (2015), Companies Control Department classification.

Barako, D. G. and Brown, A. M. (2008), "Corporate social reporting and board representation: evidence from the Kenyan banking sector", Journal of Management \& Governance, Vol. 12 No. 4, pp. 309-324.

Barako, D. G., Hancock, P. and Izan, H. (2006), "Factors influencing voluntary corporate disclosure by Kenyan companies", Corporate Governance: An International Review, Vol. 14 No. 2, pp. 107-125.

Basiddiq, H. and Hussainey, K. (2012), "Does asymmetric information drive UK dividends propensity?", Journal of Applied Accounting Research, Vol. 13 No. 3, pp. 284-297.

Beattie, V., McInnes, B. and Fearnley, S. (2011), "A methodology for analysing and evaluating narratives in annual reports: a comprehensive descriptive profile and metrics for disclosure quality attributes". Accounting forum: Elsevier, pp. 205-236.

Beretta, S. and Bozzolan, S. (2008), "Quality versus quantity: the case of forward-looking disclosure", Journal of Accounting, Auditing \& Finance, Vol. 23 No. 3, pp. 333-376. 
Bilimoria, D. (2000), "Building the business case for women corporate directors", Women on corporate boards of directors: Springer, pp. 25-40.

Botosan, C. A. (1997), "Disclosure level and the cost of equity capital", Accounting review, Vol. pp. 323-349.

Brammer, S. and Pavelin, S. (2006), "Voluntary environmental disclosures by large UK companies", Journal of Business Finance \& Accounting, Vol. 33 No. 7-8, pp. 11681188.

Campbell, K. and Mínguez-Vera, A. (2008), "Gender diversity in the boardroom and firm financial performance", Journal of business ethics, Vol. 83 No. 3, pp. 435-451.

Carney, T. F. (1972), Content analysis: A technique for systematic inference from communications. University of Manitoba Press.

Carter, D. A., Simkins, B. J. and Simpson, W. G. (2003), "Corporate governance, board diversity, and firm value", Financial Review, Vol. 38 No. 1, pp. 33-53.

Celik, O., Ecer, A. and Karabacak, H. (2006), "Disclosure of forward looking information: Evidence from listed companies on Istanbul Stock Exchange (ISE)", Investment Management and Financial Innovations, Vol. 3 No. 2, pp. 197-216.

Cerf, A. R. (1961) Corporate reporting and investment decisions. Public Accounting Research Program, Institute of Business and Economic Research, University of California.

Chang, L. S. and Most, K. S. (1985) The perceived usefulness of financial statements for investors' decisions. University Presses of Florida Gainesville.

Chau, G. and Gray, S. J. (2010), "Family ownership, board independence and voluntary disclosure: Evidence from Hong Kong", Journal of International Accounting, Auditing and Taxation, Vol. 19 No. 2, pp. 93-109.

Coffey, B. S. and Wang, J. (1998), "Board diversity and managerial control as predictors of corporate social performance", Journal of Business Ethics, Vol. 17 No. 14, pp. 15951603.

Daily, C. M., Certo, S. T. and Dalton, D. R. (2000), "International experience in the executive suite: the path to prosperity?", Strategic Management Journal, Vol. 21 No. 4, pp. 515523.

Daily, C. M., Dalton, D. R. and Cannella, A. A. (2003), "Corporate governance: Decades of dialogue and data", Academy of management review, Vol. 28 No. 3, pp. 371-382.

Davidson, R., Dey, A. and Smith, A. (2013), "Executives'“off-the-job" behavior, corporate culture, and financial reporting risk", Journal of Financial Economics.

Demsetz, H. and Lehn, K. (1985), "The structure of corporate ownership: Causes and consequences", The Journal of Political Economy, pp. 1155-1177.

Deshmukh, S. (2005), "The effect of asymmetric information on dividend policy", Quarterly Journal of Business and Economics, pp. 107-127.

Dikolli, S. S., Mayew, W. J. and Steffen, T. D. 'Honoring one's word: CEO integrity and accruals quality'. Available at SSRN: http://ssrn. com/abstract.

Dowling, M. and Aribi, Z. A. (2013), "Female directors and UK company acquisitiveness", International Review of Financial Analysis, Vol. 29, pp. 79-86.

Erhardt, N. L., Werbel, J. D. and Shrader, C. B. (2003), "Board of director diversity and firm financial performance", Corporate Governance: An International Review, Vol. 11 No. 2, pp. 102-111.

Fan, J. P. and Wong, T. J. (2002), "Corporate ownership structure and the informativeness of accounting earnings in East Asia", Journal of accounting and economics, Vol. 33 No. 3, pp. 401-425. 
García-Meca, E. and Sánchez-Ballesta, J. P. (2009), "Corporate Governance and Earnings Management: A Meta-Analysis", Corporate Governance: An International Review, Vol. 17 No. 5, pp. 594-610.

Gavious, I., Segev, E. and Yosef, R. (2012), "Female directors and earnings management in high-technology firms", Pacific Accounting Review, Vol. 24 No. 1, pp. 4-32.

Ge, W., Matsumoto, D. and Zhang, J. L. (2011), "Do CFOs Have Style? An Empirical Investigation of the Effect of Individual CFOs on Accounting Practices", Contemporary Accounting Research, Vol. 28 No. 4, pp. 1141-1179.

Gibbins, M., Richardson, A. and Waterhouse, J. (1990), "The management of corporate financial disclosure: opportunism, ritualism, policies, and processes", Journal of accounting research, pp. 121-143.

Gul, F., Hutchinson, M. and Lai, K. (2011a) Gender diversity and properties of analysts forecast: Working paper. Monash University, Sunway, Malaysia.

Gul, F. A., Srinidhi, B. and Ng, A. C. (2011b), "Does board gender diversity improve the informativeness of stock prices?", Journal of Accounting and Economics, Vol. 51 No. 3, pp. 314-338.

Haniffa, R. and Hudaib, M. (2007), "Exploring the ethical identity of Islamic banks via communication in annual reports", Journal of Business Ethics, Vol. 76 No. 1, pp. 97116.

Healy, P. M. and Wahlen, J. M. (1999), "A review of the earnings management literature and its implications for standard setting", Accounting horizons, Vol. 13 No. 4, pp. 365383.

Ho, S. S., Li, A. Y., Tam, K. and Zhang, F. (2015), "CEO Gender, Ethical Leadership, and Accounting Conservatism", Journal of Business Ethics, Vol. 127 No. 2, pp. 351-370.

Hussainey, K., Schleicher, T. and Walker, M. (2003), "Undertaking large-scale disclosure studies when AIMR-FAF ratings are not available: the case of prices leading earnings", Accounting and Business Research, Vol. 33 No. 4, pp. 275-294.

Hussainey, K. and Walker, M. (2009), "The effects of voluntary disclosure and dividend propensity on prices leading earnings", Accounting and Business Research, Vol. 39 No. 1, pp. 37-55.

Jensen, M. C. and Meckling, W. H. (1976), "Theory of the firm: Managerial behavior, Agency costs and ownership structure", Journal of Financial Economics, Vol. 3 No. 4, pp. 305-360.

Jia, Y., LENT, L. V. and Zeng, Y. (2014), "Masculinity, testosterone, and financial misreporting", Journal of Accounting Research, Vol. 52 No. 5, pp. 1195-1246.

Jizi, M. I., Salama, A., Dixon, R. and Stratling, R. (2014), "Corporate governance and corporate social responsibility disclosure: Evidence from the US banking sector", Journal of Business Ethics, Vol. 125 No. 4, pp. 601-615.

Johnson, J. E. and Powell, P. L. (1994), "Decision making, risk and gender: are managers different?", British Journal of Management, Vol. 5 No. 2, pp. 123-138.

JSC, J. S. C. (2015) General Information. Amman, Jordan (Accessed: 2-12 2015).

Karamanou, I. and Vafeas, N. (2005), "The association between corporate boards, audit committees, and management earnings forecasts: An empirical analysis", Journal of Accounting research, Vol. 43 No. 3, pp. 453-486.

Krishnan, G. V. and Parsons, L. M. (2008), "Getting to the bottom line: An exploration of gender and earnings quality", Journal of Business Ethics, Vol. 78 No. 1-2, pp. 65-76.

Li, K. and Zhao, X. (2008), "Asymmetric information and dividend policy", Financial management, Vol. 37 No. 4, pp. 673-694.

Liao, L., Luo, L. and Tang, Q. (2014), "Gender diversity, board independence, environmental committee and greenhouse gas disclosure", The British Accounting Review. 
Marston, C. and Polei, A. (2004), "Corporate reporting on the Internet by German companies", International Journal of Accounting Information Systems, Vol. 5 No. 3, pp. 285-311.

Michelon, G., Bozzolan, S. and Beretta, S. (2015), "Board monitoring and internal control system disclosure in different regulatory environments", Journal of Applied Accounting Research, Vol. 16 No. 1, pp. 138-164.

Morck, R., Shleifer, A. and Vishny, R. W. (1988), "Management ownership and market valuation: An empirical analysis", Journal of financial economics, Vol. 20, pp. 293315.

Muttakin, M. B., Khan, A. and Azim, M. I. (2015), "Corporate social responsibility disclosures and earnings quality: Are they a reflection of managers' opportunistic behavior?", Managerial Auditing Journal, Vol. 30 No. 3, pp. 277-298.

Nalikka, A. (2009), "Impact of Gender Diversity on Voluntary Disclosure in Annual Reports", Accounting \& Taxation, Vol. 1 No. 1, pp. 101-113.

Neu, D., Warsame, H. and Pedwell, K. (1998), "Managing public impressions: environmental disclosures in annual reports", Accounting, Organizations and Society, Vol. 23 No. 3, pp. 265-282.

O’Sullivan, M., Percy, M. and Stewart, J. (2008), "Australian evidence on corporate governance attributes and their association with forward-looking information in the annual report", Journal of Management \& Governance, Vol. 12 No. 1, pp. 5-35.

Pérez, G. R. (2004), "Factores explicativos de la revelación voluntaria de información sobre fuentes de ventaja competitiva empresarial", Spanish Journal of Finance and Accounting/Revista Española de Financiación y Contabilidad, Vol. 33 No. 122, pp. 705-739.

Peterson, C. A. and Philpot, J. (2007), "Women's roles on US Fortune 500 boards: Director expertise and committee memberships", Journal of Business Ethics, Vol. 72 No. 2, pp. 177-196.

Post, C., Rahman, N. and Rubow, E. (2011), "Green governance: Boards of directors' composition and environmental corporate social responsibility", Business \& Society, Vol. 50 No. 1, pp. 189-223.

Qu, W., Ee, M. S., Liu, L., Wise, V. and Carey, P. (2015), "Corporate governance and quality of forward-looking information: Evidence from the Chinese stock market", Asian Review of Accounting, Vol. 23 No. 1, pp. 39-67.

Rizk, R., Dixon, R. and Woodhead, A. (2008), "Corporate social and environmental reporting: a survey of disclosure practices in Egypt", Social Responsibility Journal, Vol. 4 No. 3, pp. 306-323.

Rose, C. (2007), "Does female board representation influence firm performance? The Danish evidence", Corporate Governance: An International Review, Vol. 15 No. 2, pp. 404413.

Saadi-Sedik, T. and Petri, M. (2006) To Smooth or Not to Smooth-The Impact of Grants and Remittances on the Equilibrium Real Exchange Rate in Jordan. International Monetary Fund.

Salama, A., Dixon, R. and Habbash, M. (2012), "An Examination of Environmental Disclosures in UK Corporate Annual Reports", Journal of Accounting, Business \& Management, Vol. 19 No. 1.

Sartawi, I. I. M., Hindawi, R. M., Bsoul, R. and Ali, A. e. J. (2014), "Board Composition, Firm Characteristics, and Voluntary Disclosure: The Case of Jordanian Firms Listed on the Amman Stock Exchange", International Business Research, Vol. 7 No. 6, pp. p67. 
Schleicher, T., Hussainey, K. and Walker, M. (2007), "Loss firms' annual report narratives and share price anticipation of earnings", The British Accounting Review, Vol. 39 No. 2, pp. 153-171.

Schrand, C. M. and Zechman, S. L. (2012), "Executive overconfidence and the slippery slope to financial misreporting", Journal of Accounting and Economics, Vol. 53 No. 1, pp. 311-329.

Siciliano, J. I. (1996), "The relationship of board member diversity to organizational performance", Journal of Business Ethics, Vol. 15 No. 12, pp. 1313-1320.

Smith, N., Smith, V. and Verner, M. (2006), "Do women in top management affect firm performance? A panel study of 2,500 Danish firms", International Journal of Productivity and Performance Management, Vol. 55 No. 7, pp. 569-593.

Souabni, S. (2011), "Predicting an uncertain future: narrative reporting and risk information".

Srinidhi, B., Gul, F. A. and Tsui, J. (2011), "Female Directors and Earnings Quality", Contemporary Accounting Research, Vol. 28 No. 5, pp. 1610-1644.

Sun, J., Liu, G. and Lan, G. (2011), "Does female directorship on independent audit committees constrain earnings management?", Journal of Business Ethics, Vol. 99 No. 3, pp. 369-382.

Thankom, A. G., Almahrog, Y. E. and Aribi, Z. A. (2015), "Female directors and earnings management: Evidence from UK companies", International Review of Financial Analysis, Vol. 39, pp. 137-146.

Tong, Y. H. (2007), "Financial reporting practices of family firms", Advances in Accounting, Vol. 23, pp. 231-261.

Uyar, A. and Kilic, M. (2012), "Influence of corporate attributes on forward-looking information disclosure in publicly traded Turkish corporations", Procedia-Social and Behavioral Sciences, Vol. 62, pp. 244-252.

Wallace, R. O., Naser, K. and Mora, A. (1994), "The relationship between the comprehensiveness of corporate annual reports and firm characteristics in Spain", Accounting and Business Research, Vol. 25 No. 97, pp. 41-53.

Wan-Hussin, W. N. (2009), "The impact of family-firm structure and board composition on corporate transparency: Evidence based on segment disclosures in Malaysia", The International Journal of Accounting, Vol. 44 No. 4, pp. 313-333.

Wang, K., Sewon, O. and Claiborne, M. C. (2008), "Determinants and consequences of voluntary disclosure in an emerging market: Evidence from China", Journal of International Accounting, Auditing and Taxation, Vol. 17 No. 1, pp. 14-30.

Watson, A., Shrives, P. and Marston, C. (2002), "Voluntary disclosure of accounting ratios in the UK", The British Accounting Review, Vol. 34 No. 4, pp. 289-313.

Welker, M. (1995), "Disclosure Policy, Information Asymmetry, and Liquidity in Equity Markets", Contemporary accounting research, Vol. 11 No. 2, pp. 801-827. 